\title{
Synthesis and characterization of CaO-loaded electrospun matrices for bone tissue engineering
}

\author{
Eliseu A. Münchow ${ }^{1,2}$ - Divya Pankajakshan ${ }^{1} \cdot$ Maria T. P. Albuquerque ${ }^{1,3}$ • \\ Krzysztof Kamocki $^{1} \cdot$ Evandro Piva $^{2} \cdot$ Richard L. Gregory ${ }^{1} \cdot$ Marco C. Bottino ${ }^{1}$
}

Received: 19 March 2015 / Accepted: 18 November 2015 / Published online: 27 November 2015

(C) Springer-Verlag Berlin Heidelberg 2015

\begin{abstract}
Objectives This study aims to synthesize and characterize biodegradable polymer-based matrices loaded with $\mathrm{CaO}$ nanoparticles for osteomyelitis treatment and bone tissue engineering.

Materials and methods Poly(e-caprolactone) (PCL) and PCL/ gelatin $(1: 1, w / w)$ solutions containing $\mathrm{CaO}$ nanoparticles were electrospun into fibrous matrices. Scanning (SEM) and transmission (TEM) electron microscopy, Fourier transformed infrared (FTIR), energy dispersive X-ray spectroscopy (EDS), contact angle (CA), tensile testing, and antibacterial activity (agar diffusion assay) against Staphylococcus aureus were performed. Osteoprecursor cell (MC3T3-E1) response (i.e., viability and alkaline phosphatase expression/ALP) and infiltration into the matrices were evaluated.

Results $\mathrm{CaO}$ nanoparticles were successfully incorporated into the fibers, with the median fiber diameter decreasing after $\mathrm{CaO}$ incorporation. The $\mathrm{CA}$ decreased with the addition of $\mathrm{CaO}$, and the presence of gelatin made the matrix very hydrophilic $\left(\mathrm{CA}=0^{\circ}\right)$. Increasing $\mathrm{CaO}$ concentrations progressively reduced the mechanical properties $(p \leq 0.030)$. CaO-loaded matrices did not display consistent antibacterial activity. MC3T3E1 cell viability demonstrated the highest levels for $\mathrm{CaO}$-loaded
\end{abstract}

Marco C. Bottino

mbottino@iu.edu

1 Division of Dental Biomaterials, Department of Biomedical and Applied Sciences, Indiana University School of Dentistry, $1121 \mathrm{~W}$. Michigan Street, Indianapolis, IN 46202, USA

2 School of Dentistry, Federal University of Pelotas - UFPel, Pelotas, RS 96065-560, Brazil

3 Graduate Program in Dentistry, Universidade Estadual Paulista, São José dos Campos Dental School, São José dos Campos, São Paulo 12245-000, Brazil matrices containing gelatin after 7 days in culture. An increased ALP expression was consistently seen for $\mathrm{PCL} / \mathrm{CaO}$ matrices when compared to PCL and gelatin-containing counterparts. Conclusions Despite inconsistent antibacterial activity, $\mathrm{CaO}$ nanoparticles can be effectively loaded into PCL or PCL/ gelatin fibers without negatively affecting the overall performance of the matrices. More importantly, $\mathrm{CaO}$ incorporation enhanced cell viability as well as differentiation capacity, as demonstrated by an increased ALP expression.

Clinical significance $\mathrm{CaO}$-loaded electrospun matrices show potential for applications in bone tissue engineering.

Keywords $\mathrm{CaO} \cdot$ Nanofibers $\cdot$ Osteomyelitis .

Electrospinning $\cdot$ Bacteria $\cdot$ MC3T3-E1

\section{Introduction}

Bone is a dynamic and heterogeneous tissue that is essentially composed of hydroxyapatite crystals embedded in a wellordered collagen fiber network [1]. Under healthy circumstances, bone is under continuous remodeling, which involves both anabolic (bone formation) and catabolic (bone resorption) processes. Regrettably, in a diseased and/or infected bone, the metabolic equilibrium state is disordered, with prevalence of mineral resorption over mineral formation, thus creating a destructive cycle that, if sustained, may lead to severe bone loss.

Among numerous adverse conditions that may affect bone structures, osteomyelitis is considered a chronic infection that can hardly be solved by using antibiotic therapy alone. Indeed, depending on the severity and duration of the infection, not only bone tissues may be destroyed but also the surrounding vascularization [2], producing a portion of dead and infected bone, also known as "sequestrum" [3]. This may hamper the delivery of systemic antibiotics to the infected site; consequently, radical 
surgical debridement of the sequestrum is vital to recover the bone tissue. Notwithstanding, osteomyelitis is usually associated with high recurrence rates (ranging from 3.9 to $24 \%$ ) [4-6], which may compromise functional bone rehabilitation.

Several techniques and combinations of materials have been used to ensure proper bone formation/healing. Bone graft materials (e.g., autologous, allogeneic, or synthetic), combined or not with repair promoters (e.g., platelet-rich plasma, enamel matrix derivative), have been extensively used for oral and maxillofacial rehabilitation purposes, displaying a high level of efficacy $[7,8]$. Hyperbaric oxygen therapy was also revealed to enhance new bone formation in diseased bone [9]. Nonetheless, these foregoing techniques do not combat the infection associated with osteomyelitis, thus requiring the systemic administration of antibiotics. Taking into consideration that tissue engineering may produce biomaterials (e.g., scaffolds, hereafter referred to as matrices) that combine both antibacterial properties and potential cell proliferation/differentiation amplification, the use of socalled bioactive matrices may become a promising approach for the healing of infected bone pathologies.

In light of this, electrospinning has been deemed as a feasible method for the preparation of three-dimensional, open, and interconnected porous structures that have been positively used for bone tissue engineering [10-14]. Moreover, these biomaterials have been used as a delivery system for several distinct substances (e.g., antibiotics, minerals, growth factors, among others), thus enhancing biological events in different sites of application [13, 15-19].

Although antibiotic-containing matrices may be interestingly applied for the treatment of osteomyelitis due to their antibacterial potential [20], currently, there is concern about the use of antibiotics, mainly because of possible cytotoxic effects that some drugs may display on human cells [21, 22], but more importantly, because of the increased likelihood of bacterial resistance $[13,23]$. In this way, the replacement of antibiotics by alternative antibacterial agents, such as metal oxides, may help to combat bone infection, since $\mathrm{CaO}$ nanoparticles have demonstrated significant antimicrobial and antifungal activities [24-26]. Furthermore, improved osteogenic ability [27] and increased osteoconductivity $[28,29]$ have been associated with the use of $\mathrm{CaO}$-containing bioactive glasses. Here, we investigated the incorporation of $\mathrm{CaO}$ nanoparticles into electrospun matrices aiming to obtain an antibacterial response against osteomyelitisrelated bacteria and improve cell viability and osteogenic differentiation for bone tissue engineering.

\section{Materials and methods}

\section{Materials}

Poly $(\varepsilon$-caprolactone) pellets (PCL, $\mathrm{Mw}=80,000)$ were procured from LACTEL Absorbable Polymers (Birmingham,
AL, USA). Gelatin type-B from bovine skin ( 225 bloom, $\mathrm{Mw}=50,000), 1,1,1,3,3,3$-hexafluoro-2-propanol (HFP), and calcium oxide nanoparticles $(\mathrm{CaO},<160 \mathrm{~nm})$ were all purchased from Sigma-Aldrich (St. Louis, MO, USA) and used as-received.

\section{Synthesis of PCL and PCL/gelatin matrices loaded with $\mathrm{CaO}$ nanoparticles}

Two different polymer solutions were prepared by dissolving PCL or PCL/gelatin (PCL/GEL, ratio of $1: 1, w / w)$ in HFP to produce $10 \mathrm{wt} \%\left(100 \mathrm{mg} \mathrm{mL}^{-1}\right)$ solutions, which were stirred overnight. The PCL solution was then loaded with distinct concentrations $(0,5,10$, and $15 \mathrm{wt} \%$, relative to the total polymer weight) of $\mathrm{CaO}$ nanoparticles, whereas the $\mathrm{PCL} /$ GEL solution was loaded with only $15 \mathrm{wt} \%$ of nanoparticles (to investigate the effect of hydrophilicity/hydrophobicity on the antibacterial activity). The mixtures were stirred for $24 \mathrm{~h}$ and sonicated for $90 \mathrm{~min}$ before their use to improve nanoparticle dispersion within the polymer solution, and then electrospun using an electrospinning system consisting of a high-voltage source (ES50P-10W/DAM, Gamma HighVoltage Research Inc., Ormond Beach, FL, USA), a syringe pump (Legato 200, KD Scientific Inc., Holliston, MA, USA), and a grounded stainless steel collecting drum connected to a high-speed mechanical stirrer (BDC6015, Caframo Limited, Georgian Bluffs, ON, CA) [17, 30]. The solutions were individually loaded into a plastic syringe (Becton, Dickson and Company, Franklin Lakes, NJ, USA) fitted with a $27 \mathrm{G}$ metallic blunt-tip (CML Supply, Lexington, KY, USA), and electrospun at room temperature, using the following parameters: a fixed spinning distance of $18 \mathrm{~cm}$, rotating mandrel with $120 \mathrm{rpm}$ of speed, flow rate of $1.5 \mathrm{~mL} / \mathrm{h}$, and varying electric voltages according to the solution. The obtained mats (hereafter referred to as matrices) were then dried under vacuum for at least $48 \mathrm{~h}$ to completely remove any remaining solvent.

\section{Characterization of the morphology and composition of the electrospun fibers}

The morphology and overall fiber architecture of the electrospun fibers were evaluated using a field-emission scanning electron microscope (FE-SEM, Model JSM-6701F, JEOL, Tokyo, Japan). Samples taken from each matrix were mounted on an aluminum stub, sputter-coated with gold-palladium, and imaged at $5-7 \mathrm{kV}$. The diameter of the fibers was then calculated using Image J software (National Institutes of Health, Bethesda, MD, USA) and by measuring 50 singlefibers per each image obtained (three images/group) at the same magnification $(\times 5000)$. Energy dispersive X-ray spectroscopy (EDS) was performed under FE-SEM to semiquantitatively analyze the chemical composition of the fibers. 
The incorporation of the $\mathrm{CaO}$ nanoparticles into the polymer fibers was investigated using transmission electron microscopy (TEM, Model JEM-2010, JEOL). The chemical characteristics and $\mathrm{CaO}$ incorporation of all the matrices were also evaluated by Fourier transform infrared spectroscopy (FTIR) in the attenuated total reflection mode (ATR/FTIR-4100, JASCO Analytical Instruments, Easton, MD, USA), over the range $700-4000 \mathrm{~cm}^{-1}$ at a resolution of $4 \mathrm{~cm}^{-1}$.

\section{Contact angle}

The unfilled and $\mathrm{CaO}$-incorporated solutions were electrospun into fibers on microscope glass coverslips (Fisherbrand, Fisher Scientific UK Ltd., Loughborough, UK) mounted on the rotating mandrel ( $n=10 /$ group). The electrospinning parameters were the same as aforementioned. The surface CA of the fibrous matrices was measured using a goniometer (Model PG-2, Gardco, Paul N. Gardner Company Incorporated, Pompano Beach, FL, USA) by dropping three consecutive drops of distilled water $(\sim 5 \mu \mathrm{L})$ per sample. The measured angles were then averaged.

\section{Mechanical properties}

The mechanical properties (i.e., tensile strength, Young's modulus, and elongation at break) of all the obtained matrices were assessed by uniaxial tensile testing (expert 5601, ADMET, Norwood, MA, USA). Rectangular samples $\left(15 \times 3 \mathrm{~mm}^{2}\right)$ were tested $(n=8)$ under both dry (immediate testing without storage) or wet (tested after storage in PBS solution for $24 \mathrm{~h}$ ) conditions at a crosshead speed of $1 \mathrm{~mm} \mathrm{~min}^{-1}$. The specimen thickness was determined by measuring with caliper at five locations. Mechanical data were obtained from the stress-strain curves of each specimen and the results were reported as mean \pm standard deviation (SD).

\section{Antibacterial activity}

The minimum inhibitory concentration (MIC) of the $\mathrm{CaO}$ powder was determined using suspensions of $\mathrm{CaO}$ nanoparticles in PBS at the following concentrations: 100, 250, 500, $1000,2500,5000,10,000$, and $20,000 \mu \mathrm{g} / \mathrm{mL}$. Staphylococcus aureus was chosen as the bacterial agent in this study because it is a common pathogen found in osteomyelitis cases [31, 32]. The antibacterial activity against S. aureus (ATCC 6538) was tested using an agar diffusion assay ( $n=3$ /group), which was aerobically cultivated in Brain Heart Infusion (BHI) broth supplemented with $5 \mathrm{~g}$ yeast extract/L at $37^{\circ} \mathrm{C}$. A $10-\mu \mathrm{L}$ aliquot of each $\mathrm{CaO}$ suspension was dropped on cultured blood agar plates containing $S$. aureus bacterial lawns and incubated for $48 \mathrm{~h}$. Then, the matrices were also tested in order to evaluate their antibacterial potential. Briefly, disk-shaped specimens $(5 \mathrm{~mm}$ in diameter) were prepared and sterilized by ultraviolet irradiation for $1 \mathrm{~h}$ (30 min each side), before placing on the cultured blood agar plates as previously described [16].

\section{Cell culture}

Mouse-calvaria-derived osteoprecursor cells (ATCC, CRL2593, MC3T3-E1 Subclone 4, American Type Culture Collection, Rockville, MD, USA) were cultured at $37^{\circ} \mathrm{C}$ under $5 \% \mathrm{CO}_{2} / 95 \%$ air in minimum essential medium (alphaMEM, Gibco, Grand Island, NY, USA) supplemented with $10 \%$ fetal bovine serum (Gibco), $1 \%$ L-glutamine (Sigma), and a $1 \%$ antibiotic formulation (penicillin G sodium, streptomycin sulfate, Sigma) [33]. The media was changed every other day and the cells were trypsinized upon reaching confluence. Cells at passages $12-15$ were used. Worth mentioning, all electrospun matrices were cut into $15 \times 15 \mathrm{~mm}^{2}$ samples and disinfected by $70 \%$ ethanol for $30 \mathrm{~min}$, rinsed once with $2 \mathrm{~mL}$ of sterile $0.9 \%$ PBS (Sigma), and soaked in the previously described culture medium for $30 \mathrm{~min}$ prior to cell seeding.

\section{Cell adhesion}

MC3T3-E1 cells at passage 13 were seeded at a density of 10 , 000 cells/matrix. At day 3, the matrices were removed from the media, washed in PBS, and fixed using $3.7 \%$ formaldehyde (Sigma). After washing in PBS $(3 \times)$, the cells were permeabilized with $0.1 \%$ Triton X-100 (Sigma) for $10 \mathrm{~min}$. The matrix-cells constructs were washed with PBS $(3 \times)$ and incubated with $1 \%$ bovine serum albumin for 30 min to reduce nonspecific background staining. Next, the matrices were once again washed in PBS prior to rhodamine-phalloidin (1:1000 dilution; Invitrogen Life Technologies, Gaithersburg, MD, USA) incubation for $1 \mathrm{~h}$, in the dark, for actin filament staining. Finally, the constructs were washed in PBS $(3 \times)$, followed by staining using Syto 13 (1:1000 dilution; Invitrogen Life Technologies) for nucleic acid staining, washed in PBS, imaged using a confocal/2-photon Olympus FV1000 MPE system (Olympus America, Central Valley, PA, USA), and then analyzed using the Fluoview software (v.3.0). Images $(512 \times 512$ pixels; $221 \times 221 \mathrm{\mu m}^{2}$ ) were captured with a XLUMPLFL $20 \times$ ( $0.95 \mathrm{NA})$ objective at a scan rate of $4.0 \mu \mathrm{s} /$ pixel. Images are maximum intensity projection of Z-slices of ca. $50 \mu \mathrm{m}$ depth.

\section{Cell viability}

Cell viability was assessed using the PMS-MTS one solution kit (Promega Corporation, Fitchburg, WI, USA) after 3, 5, and 7 days. MC3T3-E1 cells at were seeded at a density of 10,000 cells/matrix. A total $100 \mu \mathrm{L}$ of the assay reagent was added to each sample containing $500 \mu \mathrm{L}$ of fresh, fully supplemented medium. Following $2 \mathrm{~h}$ of incubation at $37^{\circ} \mathrm{C}$ and $5 \% \mathrm{CO}_{2}$ in 
a humidified atmosphere, $100 \mu \mathrm{L}$ from each 24-well plate was transferred into wells of a 96 -well plate in triplicate. Absorbance was determined at $490 \mathrm{~nm}$ using a plate reader. The MC3T3-E1 cells, seeded directly into 24-well plates, served as a high control. As a background, optical density measured at $650 \mathrm{~nm}$ was used for samples, per the manufacturer's recommendations. Two supplementary samples per group and per time point were included in the cell experiment to qualitatively assess cell-matrix interaction via SEM (JSM5310LV, JEOL, Tokyo, Japan).

\section{Alkaline phosphatase assay}

The osteogenic differentiation of MC3T3-E1 cells on the synthesized matrices was determined by alkaline phosphatase (ALP; SensoLyte pNPP, AnaSpec, Fremont, CA, USA) activity at days $1,3,7$, and 14 . The assay is based on the conversion of $p-$ nitrophenyl phosphate (pNPP) to p-nitrophenol, which is measured at $405 \mathrm{~nm}$. Briefly, the cells were seeded on the $15 \times 15 \mathrm{~mm}^{2}$ samples at a density of $3 \times 10^{6}$ and cultured in osteogenic differentiation media (Lonza, Walkersville, MD, USA) for 14 days. At the predetermined timepoints, the cells were digested using lysis buffer $(300 \mu \mathrm{L})$ and subjected to three freeze-thaw cycles. The cell suspension was centrifuged for $10 \mathrm{~min}$ at $4{ }^{\circ} \mathrm{C}$. Fifty microliters of the supernatant was added to each well of a 96-well plate and allowed to react for $15 \mathrm{~min}$ with $50 \mu \mathrm{L}$ of pNPP substrate solution at $37^{\circ} \mathrm{C}$. Standards of 0 $300 \mathrm{ng} / \mathrm{mL}$ p-nitrophenol were run in parallel. The absorbance of standards and samples were read at $405 \mathrm{~nm}$. Protein concentrations of the sample supernatants were determined using a Pierce $^{\mathrm{TM}}$ assay kit (Thermo Scientific, Waltham, MA, USA).

\section{Statistical analysis}

Data were statistically analyzed (SigmaPlot version 12, Systat Software Inc., San Jose, CA, USA) using the Kruskal-Wallis one-way analysis of variance (ANOVA) on ranks for heteroscedastic data (fiber diameter) and one-way ANOVA (contact angle and cell viability) or two-way ANOVA (mechanical characteristics) for homoscedastic data. The StudentNewman-Keul's and Tukey's tests were used, respectively, for multiple comparisons of heteroscedastic and homoscedastic data. Pearson correlation was used to correlate the contact angle with $\mathrm{CaO}$ concentration. The level of significance for all analyses was set at $\alpha=0.05$.

\section{Results}

\section{Morphological analysis}

All matrices demonstrated homogeneous fibers, although the incorporation of $\mathrm{CaO}$ resulted in the occurrence of some bead- like structures, as well as in the occurrence of clusters along the length of some fibers (Fig. 1). According to the statistical analysis, the presence of gelatin increased the median fiber diameter compared to the gelatin-free fibers (inset table in Fig. 1). Moreover, the greater the incorporation of $\mathrm{CaO}$, the thinner the fibers $(p>0.05)$.

\section{Chemical and ultrastructure analyses}

EDS analysis confirmed the incorporation of $\mathrm{CaO}$ within the PCL matrix (Fig. 2a), as seen by the characteristic peaks in the spectrum obtained from the PCL nanocomposite matrix loaded with $15 \mathrm{wt} \%$ of $\mathrm{CaO}$. The FTIR analysis also revealed incorporation of $\mathrm{CaO}$ into the PCL (Fig. 2b) and PCL/GEL matrices (Fig. 2c). Appearance of the peak located at $876 \mathrm{~cm}^{-1}$ could be observed in the $\mathrm{CaO}$ powder and also in all of the $\mathrm{CaO}$-loaded matrices, but not in the neat membrane. Moreover, the presence of another peak located at $3641 \mathrm{~cm}^{-1}$ was seen within both the high-concentrated $\mathrm{CaO}$ loaded matrices and the $\mathrm{CaO}$ powder. The incorporation of gelatin into the PCL/GEL matrix was also confirmed by the occurrence of three characteristic peaks (amide-A $/ 3290 \mathrm{~cm}^{-1}$, amide-I/1627 $\mathrm{cm}^{-1}$, and amide-II/1524 $\mathrm{cm}^{-1}$ ) (Fig. 2c). In addition, the TEM images showed that the $\mathrm{CaO}$ nanoparticles were distinct in shape/size (Fig. 3a), although found in the nano-size range (average size of $67 \mathrm{~nm}$ ). Furthermore, the images clearly show the difference between neat and nanocomposite fibers; while the former were visually clear and smooth (Fig. 3b), the latter showed a rougher surface and areas embedded with $\mathrm{CaO}$ nanoparticles (Fig. 3c, d).

\section{Contact angle}

The PCL-based matrices, regardless of the presence of $\mathrm{CaO}$, presented a hydrophobic surface (i.e., contact angle higher than $90^{\circ}$ ) (Fig. 4a). However, according to the regression model used, the greater the $\mathrm{CaO}$ concentration, the lower the contact angle achieved (Fig. 4b). By contrast, the PCL/GELbased matrix demonstrated a very hydrophilic surface (contact angle equal to $0^{\circ}$ ) (Fig. 4a), which was significantly lower $(p<0.001)$ compared to the other matrices evaluated (Fig. 4c).

\section{Mechanical characteristics}

Based on the statistical analysis, there was a significant interaction $(p \leq 0.001)$ between the factors investigated (i.e., "matrix type" versus "storage condition"). The results are shown in Table 1. With regard to the storage condition factor, the PCL-based matrices demonstrated similar mechanical performance under both "dry" and "wet" conditions $(p \geq 0.052)$, except for the matrix loaded with 15 wt $\%$ of $\mathrm{CaO}$, which exhibited lower $(p=0.003)$ Young's modulus after wet storage when compared to specimens that were stored dry. With 


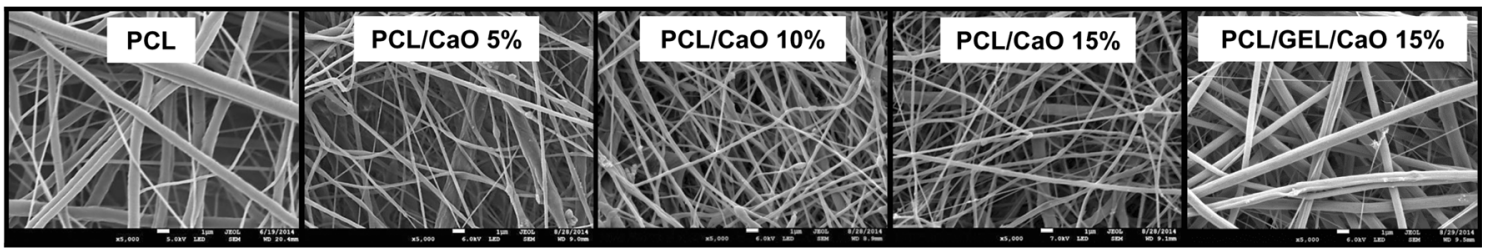

\begin{tabular}{|c|c|c|c|c|c|}
\hline \multicolumn{5}{|c|}{ Median fiber diameter $(\mathrm{nm})$ of the membranes } & \multirow{3}{*}{$\begin{array}{l}\text { Distinct superscript } \\
\text { letters after medians } \\
\text { indicate statistically } \\
\text { significant differen- } \\
\text { ces among groups } \\
(p<0.05) \text {. }\end{array}$} \\
\hline PCL & $\mathrm{PCL} / \mathrm{CaO} 5 \%$ & $\mathrm{PCL} / \mathrm{CaO} 10 \%$ & $\mathrm{PCL} / \mathrm{CaO} 15 \%$ & PCL/GEL/CaO 15\% & \\
\hline $232.1^{\mathrm{B}}$ & $207.9^{c}$ & $202.2^{c}$ & $184.8^{\mathrm{D}}$ & $277.2^{\mathrm{A}}$ & \\
\hline
\end{tabular}

Fig. 1 Representative SEM micrographs and median fiber diameter (inset table) for the processed electrospun polymer-based matrices. Median fiber diameter was calculated using 150 fibers seen on three distinct SEM images

regard to the matrix-type factor, the greater the content of $\mathrm{CaO}$ incorporated into the matrix, the lower the mechanical characteristics $(p \leq 0.030)$. The gelatin-based matrix showed higher tensile strength $(p \leq 0.025)$, Young's modulus $(p \leq 0.001)$, and elongation at break $(p \leq 0.043)$ when compared to the PCL matrix containing $15 \mathrm{wt} \%$ of $\mathrm{CaO}$, except for the Young's modulus of specimens stored in wet condition, which did not differ from each other $(p=0.459)$. Wet storage reduced $(p<0.001)$ the properties of the gelatin-based matrix compared to dry storage.

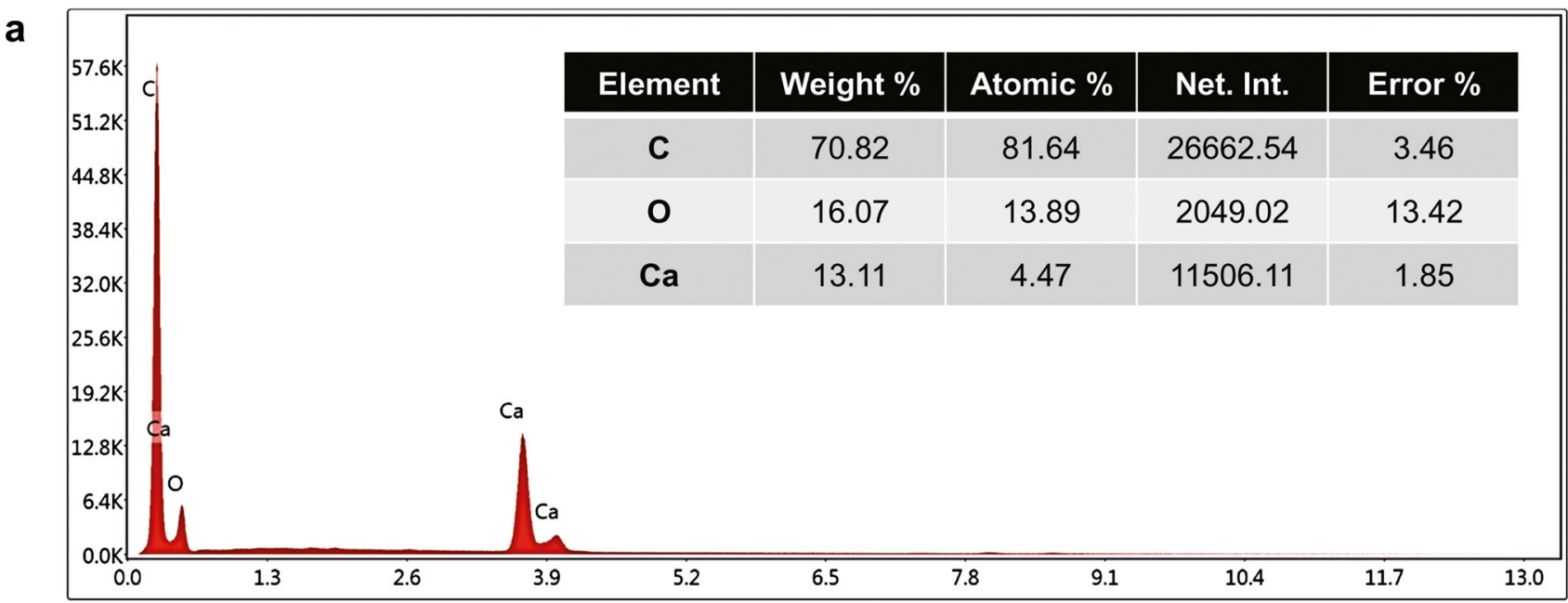

Lsec: 30.00 Cnts 0.000 keV Det: Octane Super Det
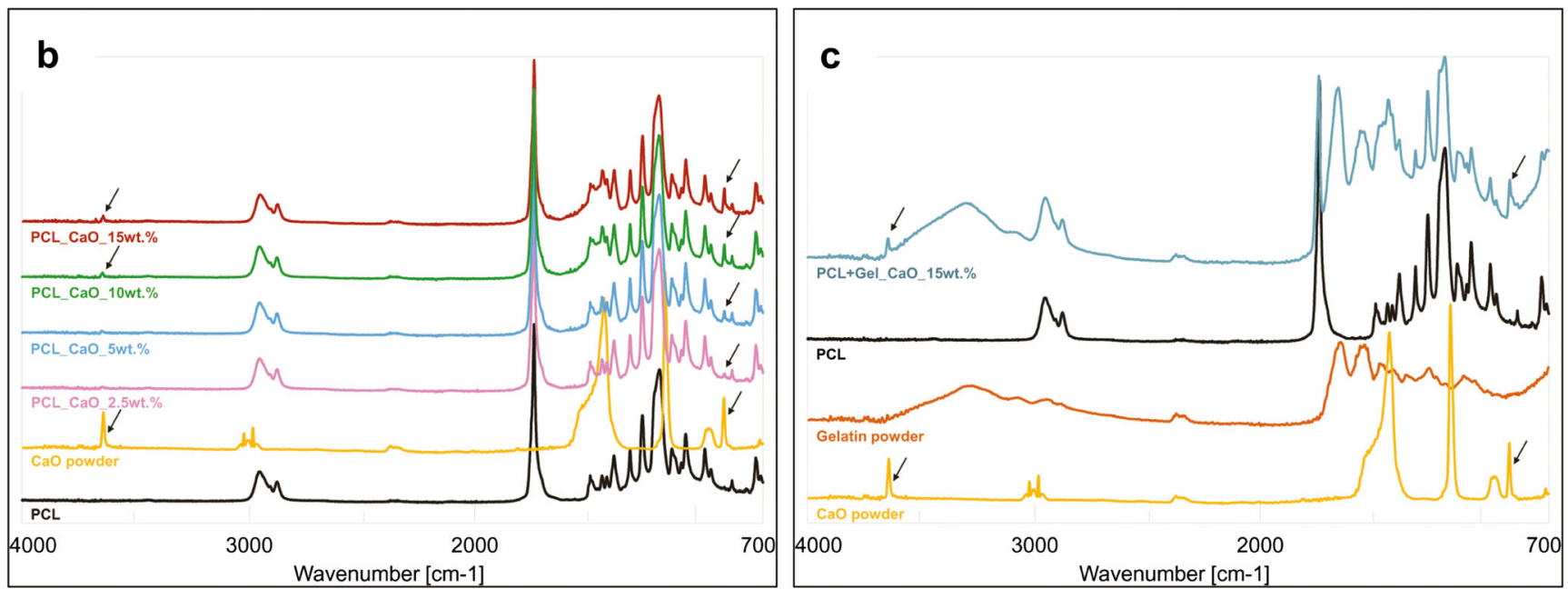

Fig. 2 a Representative image shows the EDS spectrum of the PCL-based matrix containing $15 \mathrm{wt} \%$ CaO nanoparticles. b FTIR spectra for the PCLand $\mathbf{c} \mathrm{PCL} / \mathrm{GEL}$-based matrices, revealing the incorporation of $\mathrm{CaO}$ (black arrows) and gelatin 
Fig. 3 a TEM image $(\times 150,000$ magnification) shows the overall morphology and size distribution of the $\mathrm{CaO}$ nanoparticles used. $\mathbf{b}$ TEM images demonstrate a neat/pure PCL fiber and $\mathbf{c}, \mathbf{d}$ a $\mathrm{CaO}$-loaded fiber. The image on the left down and the images on the right, respectively, illustrate, magnifications of $\times 30,000$ and $\times 98,000$
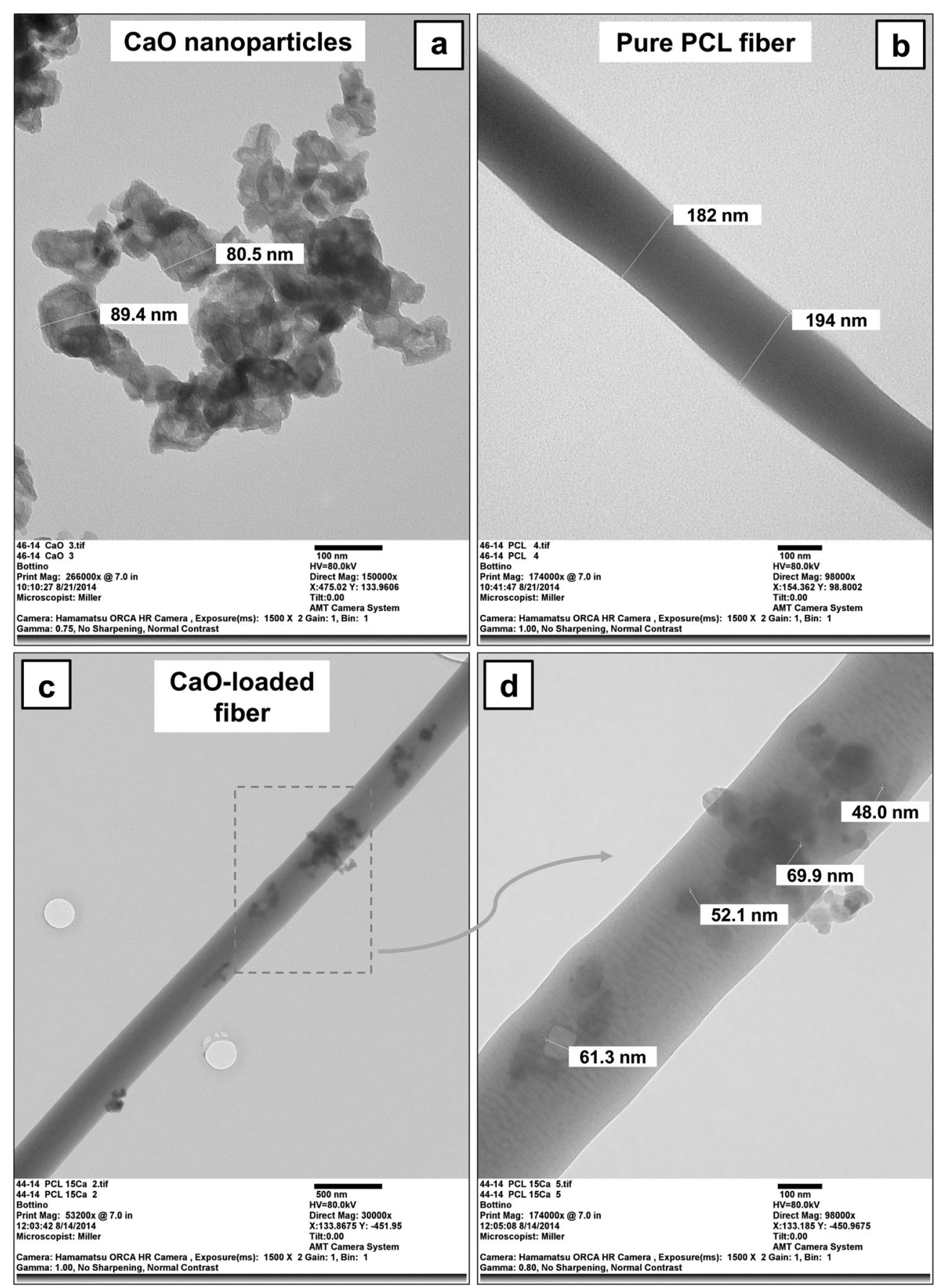

\section{Antibacterial activity}

The antibacterial activity test was conducted three separate times in triplicate. In the first experiment, a positive inhibition halo could be observed for the gelatinbased matrix containing 15 wt\% of $\mathrm{CaO}$ (Fig. 5a), although this effect was not observed with the gelatin-free matrices. Two other experiments were performed to further confirm the data; however, in both experiments, the distinct $\mathrm{CaO}$ suspensions, as well as the matrices containing $\mathrm{CaO}$ nanoparticles, demonstrated no antibacterial activity against $S$. aureus (Fig. 5b).

\section{Cell adhesion}

MC3T3-E1 cells were able to adhere and proliferate on all the synthesized matrices. However, cells on $\mathrm{CaO}$-loaded matrices appeared to spread and migrate more when compared to the pure PCL matrix (Fig. 6). The PCL/GEL/CaO matrix seemed to have the greatest cell number. Figure 6 display images that 


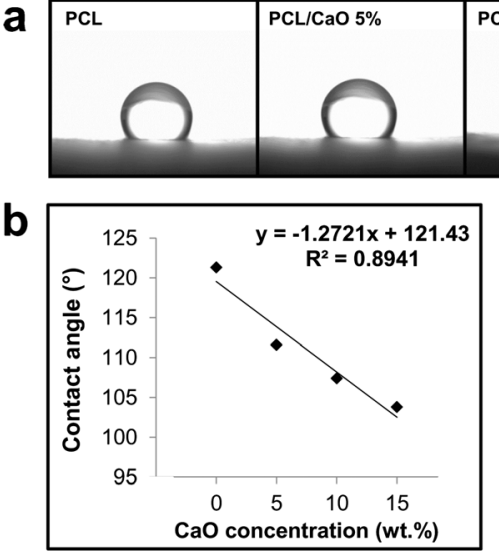

Fig. 4 a Images of the contact angle (CA) formed between water and the processed matrices. $\mathbf{b}$ The linear regression model shows the inverse relationship between $\mathrm{CaO}$ concentration and $\mathrm{CA}$. c The inset table shows the mean $\mathrm{CA}$ obtained for each matrix. All matrices were

represent the maximum intensity projections of the Z-slices. The $\mathrm{Z}$ images obtained by confocal microscopy revealed cell infiltration along the depth of the matrix (Fig. 6).

\section{Cell viability}

Quantitative data is shown in Fig. 7. MC3T3-E1 cell viability increased in a time-dependent fashion, with cultures at day 7 displaying a higher $(p<0.001)$ number of cells than cultures at day 3 . The only exception occurred in cells cultured on the PCL matrix containing $15 \mathrm{wt} \%$ of $\mathrm{CaO}$, which showed increased viability until day 5 , but then a significant $(p<0.001)$ reduction at day 7 . The gelatin-based matrix allowed the highest levels of cell viability obtained in the study, although it was not different $(p \geq 0.541)$ from the PCL matrices containing no $(0 \mathrm{wt} \%)$ or low $(5 \mathrm{wt} \%)$ content of $\mathrm{CaO}$ after 7 days of cell culture. Qualitative SEM images of MC3T3-E1 proliferation after direct contact with the processed matrices are shown in Fig. 8. The cells demonstrated a fairly well spread-out distribution over the surface of the matrices, and extensions of pseudopodia were present surrounding the center of the cells.

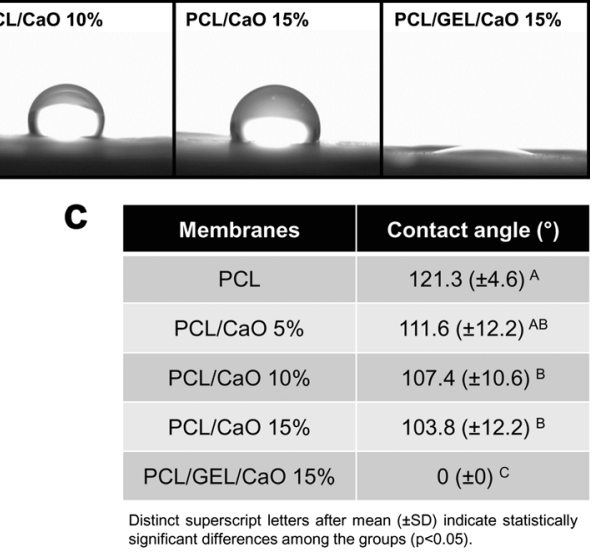

electrospun over glass coverslips ( $n=10$ /group). Three consecutive drops of distilled water were applied per sample. The measured angles were then averaged

\section{ALP activity}

An increased ALP expression was consistently seen for PCL/ $\mathrm{CaO}$ matrices when compared to PCL and gelatin-containing counterparts (Fig. 9) demonstrating the high mineralization capability of cells seeded on $\mathrm{CaO}-$ loaded, but gelatin-free, electrospun fibrous matrices.

\section{Discussion}

Considering that cells need a proper substrate to attach to and to proliferate in, the morphological structure of the processed matrices was evaluated. According to the SEM micrographs shown in Fig. 1, all matrices presented a homogeneous structure, although the presence of $\mathrm{CaO}$ resulted in the occurrence of some bead-like structures. It can be suggested that the inherent high surface energy of nanoparticles led to their agglomeration [15], forming clusters along the fiber length that have probably originated from the beads. Surprisingly, no beads were seen within the PCL/GEL-based matrix despite the presence of $15 \mathrm{wt} \%$ of $\mathrm{CaO}$. This, perhaps, is due to

Table 1 Mechanical characteristics (mean \pm standard deviation) of the membranes synthesized in the study, under dry and wet conditions

\begin{tabular}{|c|c|c|c|c|c|c|}
\hline \multirow[t]{2}{*}{ Membranes } & \multicolumn{2}{|c|}{ Tensile strength (MPa) } & \multicolumn{2}{|c|}{ Young's modulus (MPa) } & \multicolumn{2}{|c|}{ Elongation at break (\%) } \\
\hline & Dry & Wet & Dry & Wet & Dry & Wet \\
\hline PCL & A $2.5 \pm 0.2 \mathrm{a}$ & A $2.5 \pm 0.5 \mathrm{a}$ & B $10.1 \pm 1.8 \mathrm{a}$ & A $10.4 \pm 3.0 \mathrm{a}$ & A $77.7 \pm 3.0 \mathrm{a}$ & A $77.8 \pm 6.8 \mathrm{a}$ \\
\hline $\mathrm{PCL} / \mathrm{CaO} 5 \%$ & $\mathrm{C} 1.5 \pm 0.4 \mathrm{a}$ & B $1.2 \pm 0.4 \mathrm{a}$ & $\mathrm{BC} 7.7 \pm 1.8 \mathrm{a}$ & B $6.9 \pm 2.4 \mathrm{a}$ & C $56.8 \pm 11.4 \mathrm{a}$ & B $54.4 \pm 8.9 \mathrm{a}$ \\
\hline $\mathrm{PCL} / \mathrm{CaO} 10 \%$ & D $0.8 \pm 0.3 \mathrm{a}$ & $\mathrm{C} 0.8 \pm 0.3 \mathrm{a}$ & C $5.9 \pm 0.9 \mathrm{a}$ & B $5.8 \pm 2.6 \mathrm{a}$ & D $24.6 \pm 5.5 \mathrm{a}$ & D $16.4 \pm 3.7 \mathrm{a}$ \\
\hline $\mathrm{PCL} / \mathrm{CaO} 15 \%$ & E $0.2 \pm 0.1 \mathrm{a}$ & E $0.1 \pm 0.1 \mathrm{a}$ & D $3.8 \pm 1.9 \mathrm{a}$ & C $1.9 \pm 1.6 b$ & E $6.9 \pm 1.4 \mathrm{a}$ & $\mathrm{D} 8.4 \pm 2.0 \mathrm{a}$ \\
\hline $\mathrm{PCL} / \mathrm{GEL} / \mathrm{CaO} 15 \%$ & B $2.1 \pm 0.3 \mathrm{a}$ & D $0.5 \pm 0.3 b$ & A $27.7 \pm 4.1 \mathrm{a}$ & C $2.1 \pm 0.9 \mathrm{~b}$ & B $69.1 \pm 17.0 \mathrm{a}$ & C $33.3 \pm 3.8 b$ \\
\hline
\end{tabular}

While distinct uppercase letters in the same column indicate statistically significant differences among the membranes tested $(p<0.05)$, distinct lowercase letters in the same row represent a significant difference between the storage conditions investigated $(p<0.05)$ 
Fig. 5 Macrophotographs of the agar plates obtained in the first (a) and third (b) experiments, respectively, showing the presence of an inhibition halo for the PCL/GEL matrix containing $15 \mathrm{wt} \% \mathrm{CaO}$ and the absence of the inhibition halo for the $\mathrm{CaO}$ loaded matrices
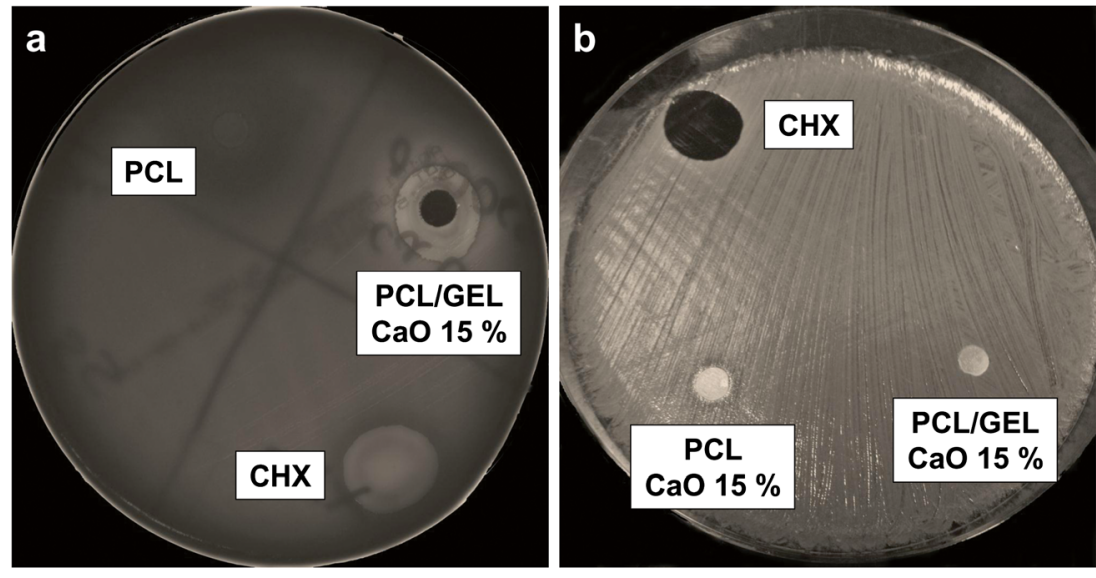

increased viscosity of the gelatin-based polymer solution, which allowed improved chain entanglement during electrospinning and, consequently, the production of thicker fibers [34]. Indeed, the increase in fiber diameter may have played a positive and significant role in $\mathrm{CaO}$ distribution, leading to non-detectable agglomeration of the nanoparticles. Regarding the fiber diameter, the incorporation of $\mathrm{CaO}$ progressively reduced the diameter of fibers, probably due to the increase in electrical conductivity of the polymer solution (i.e., $\mathrm{CaO}=$ metallic oxide), which acted by increasing the charge density on the surface of the ejected spinning jet, followed by a reduction in self-repulsion tension, and consequently, a reduction in the thickness of the fibers [15]. Moreover, it can be noted that the greater the $\mathrm{CaO}$ concentration, the lower the apparent porosity of the matrices. However, porosity is an important characteristic for cell migration and infiltration [35], since the cells need space to move within the architecture of the matrix; this characteristic was not investigated in the present study. Despite the distinct fiber architectures obtained, it can be speculated that all matrices displayed a satisfactory morphology, so they appeared suitable for bone tissue engineering applications.

Although the fibers shown in Fig. 1 do not provide a conclusive visual detection of the presence of $\mathrm{CaO}$ nanoparticles, the EDS, FTIR, and TEM analyses confirmed their successful incorporation into the processed matrices. The EDS analysis is an analytical technique used to provide semi-quantitative chemical information. According to Fig. 2a, two calcium peaks were detected, corresponding to approximately $13 \mathrm{wt} \%$ (inset table) of all chemical elements present within the PCL-based polymer nanofibers incorporated with $15 \mathrm{wt} \%$ of $\mathrm{CaO}$ (theoretical amount). This confirmed that the amount of $\mathrm{CaO}$ added to the polymer solution was almost identical to the amount of $\mathrm{CaO}$ incorporated into the nanofibers. The presence of $\mathrm{CaO}$ and gelatin was also detected by the FTIR analysis (Fig. 2b, c), and it is worthwhile to note that the higher the $\mathrm{CaO}$ content, the greater the intensity of $\mathrm{CaO}$-related peaks in the spectra.

Considering the successful $\mathrm{CaO}$ incorporation into the fibers, this study also investigated the effects of these
Fig. 6 Confocal images (scale bar $=20 \mu \mathrm{m}$ ) demonstrating cell adhesion on the matrices. a PCL; b $\mathrm{PCL} / \mathrm{CaO} 5 \%$; c $\mathrm{PCL} / \mathrm{CaO}$ $10 \%$; d PCL/CaO $15 \%$; and e $\mathrm{PCL} / \mathrm{GEL} / \mathrm{CaO} 15 \%$. Images are maximum intensity projection of Z-slices (ca. $50 \mu \mathrm{m}$ depth). The matrices are false colored gray, the actin stained cells appear red, and the nucleus is stained green. The colocalization of red actin and green nucleus appear as yellow. The $\mathrm{XZ}$ and $\mathrm{YZ}$ images represent of specific line are also shown to demonstrate the cell infiltration on the matrices.

Triplicate samples were measured
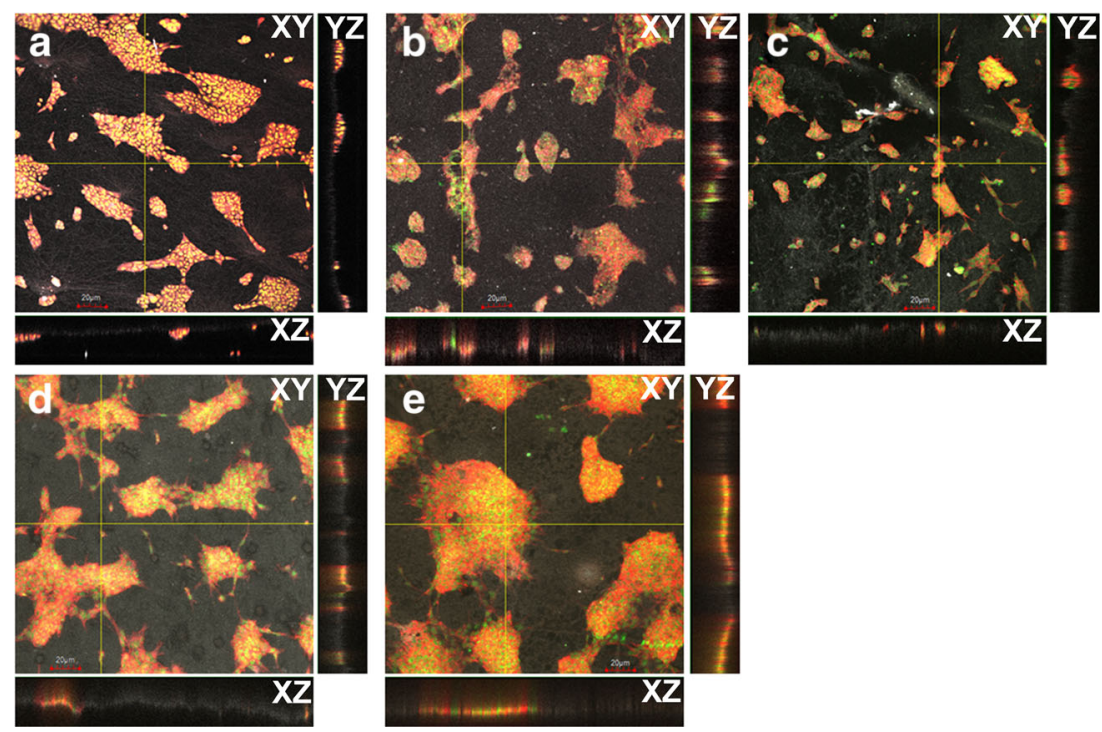
Fig. 7 Graph and inset table showing the mean and standard deviation $( \pm \mathrm{SD})$ of the percentage viability $(N=4)$ of the MC3T3-

E1 cells cultured on the

electrospun matrices.

Quadruplicate samples were measured

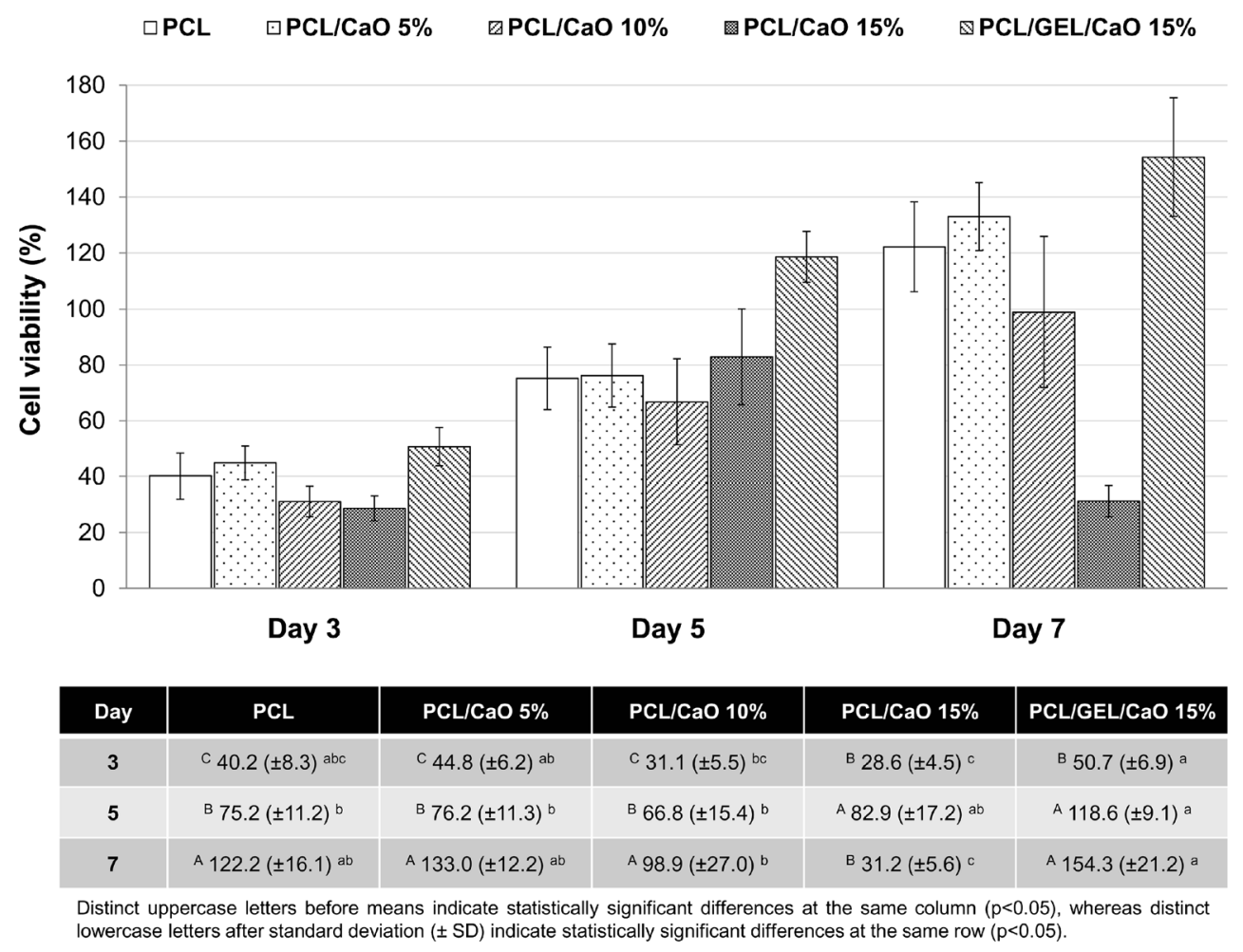

nanoparticles on the final wettability of the matrices, especially because optimal wettability is an important characteristic to cell adhesion and proliferation [13]. Although the matrices became less hydrophobic with the addition of $\mathrm{CaO}$ (Fig. 4), they still presented low wettability. Indeed, only the presence of gelatin produced a hydrophilic surface, which means that the PCL/GEL-based matrix would be able to absorb moisture/ fluids and proteins present in the implantation site. According to some studies, hydrophilic matrices/scaffolds may improve cell affinity, cell proliferation, wound healing, and cell
Fig. 8 Representative SEM micrographs demonstrating the morphology, spreading, and distribution of cells cultured on the processed matrices at each time point investigated. At each subgroup tested, the upper and lower images, respectively, illustrate magnifications of $\times 500$ and $\times 1500$

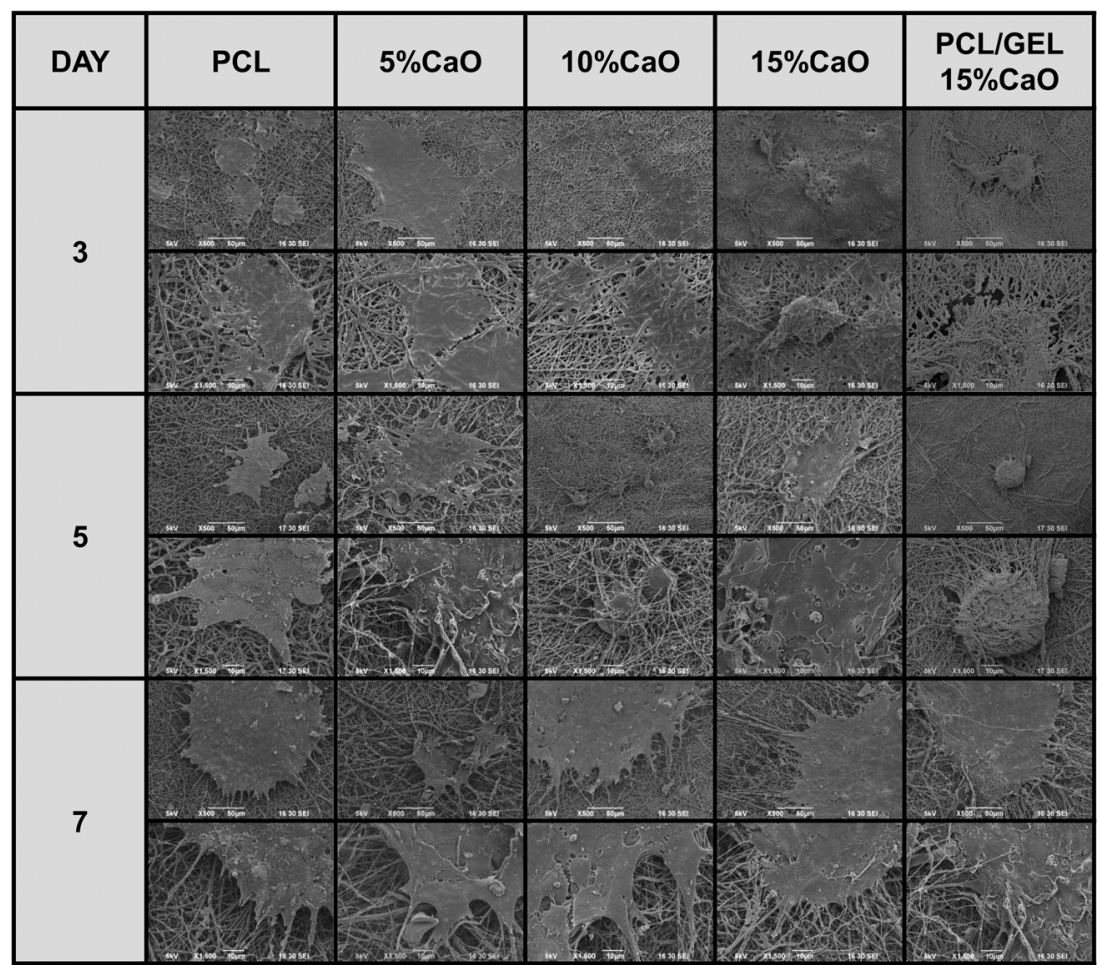


Fig. 9 Alkaline phosphatase activity (ALP) of MC3T3-E1 cells at $1,3,7$, and 14 days cultured on the various electrospun matrices. ALP was normalized by the protein concentration, with units of (ng $\mathrm{pNP} / \mathrm{mL}) /$ milligram protein. Triplicate samples at each time point were measured. The statistically different group $(p<0.05)$ from the PCL is represented by asterisk above the bar
口DAY 1

๑DAY 3

圈DAY 7

DAY 14

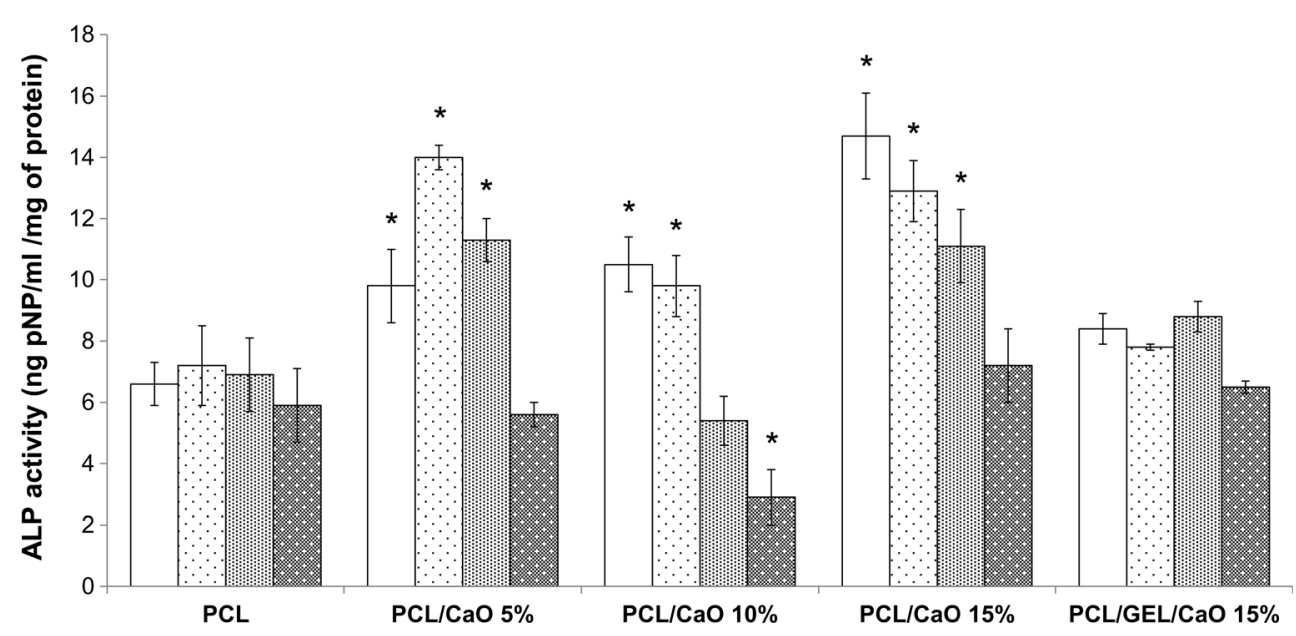

spreading/migration events when compared to hydrophobic ones [36-40]. Interestingly, Rajzer et al. [41] recently demonstrated that, despite PCL scaffolds acting as a mechanically strong skeleton for bone tissue regeneration, the incorporation of gelatin into the PCL matrix resulted in enhanced cell spreading and mineralization activity. Notably, the gelatinbased scaffold prepared in that study was constituted from calcium phosphate nanoparticles; thus, the positive cell response obtained could also be due to the presence of nanoparticles. Nevertheless, the combination of gelatin and PCL has been truly revealed as an effective matrix for the preparation of biomimetic scaffolds applied in bone tissue engineering $[41,42]$, which may, in turn, be intrinsically related to the gain in wettability seen with gelatin incorporation. However, equilibrium between hydrophobicity and hydrophilicity is essential in order to produce physico-mechanically stable matrices. Considering the results shown in Table 1, although the incorporation of gelatin resulted in 10.5, 7.3, and 10.0 times higher tensile strength, Young's modulus, and elongation at break, respectively, as compared to its gelatin-free counterpart (i.e., the PCL matrix containing $15 \mathrm{wt} \%$ of $\mathrm{CaO}$ ) (Table 1), this effect was not observed after wet storage of the samples. Indeed, a significant reduction in properties was obtained, which ranged from a 2.1- to a 13.2-fold decrease, depending on the mechanical property tested. This is probably related to the hydrophilic nature of gelatin, which does not naturally cross-link to the main polymer chain, leading to fast hydrolytic degradation of the system, and consequently, to strength reduction [43]. By contrast, the mechanical properties of the gelatin-free matrices remained mostly unchanged after wet storage, and the hydrophobic nature of PCL is the most reasonable explanation for this result. Another finding of the present study was that the incorporation of $\mathrm{CaO}$ reduced the strength of the matrices, corroborating the findings of a previous study that stated ceramic non-woven fabrics (i.e., the $\mathrm{CaO}-$ loaded matrices synthesized here) are brittle in nature, thus affecting the mechanical behavior of the biomaterial [27]. Notwithstanding, the presence of calcium-based compounds in scaffolds was revealed to positively aid in bioactivity characteristics, thus overcoming the negative effects on mechanical properties.

$\mathrm{CaO}$ was chosen in this study especially because of its previous effective antimicrobial potential [24, 28, 29], which is mostly believed to be due to the production of reactive oxygen species (ROS) that may ultimately penetrate through bacterial cell matrices, decreasing cell activity events, and consequently, bacterial survival. Nonetheless, only one of the three independent experiments resulted in antibacterial activity against the targeted bacteria (Fig. 5a), and perhaps only for the gelatin-based matrix. This positive result was, at first, considered promising; however, no antibacterial activity was obtained in the next two rounds of experiments (Fig. 5b), regardless of the matrix tested. Although it may be difficult to explain these findings, there are some important aspects related to the characteristics and processing conditions of nanoparticles that could have influenced this outcome. First, it has been revealed that the size of nanoparticles may affect their antibacterial potential, with the smaller the size, the greater the activity [44]; second, calcination (i.e., a thermal treating process) of $\mathrm{CaO}$ nanoparticles was revealed to improve bacterial killing when compared to untreated nanoparticles [45]. The nanoparticles used in the present study were situated in the nano-size range (Fig. 3a), showing an average size of $67 \mathrm{~nm}$, which, in fact, was considerably higher than the 18-nm-sized nanoparticles used in the study by Roy et al. [24]. This difference in size of nanoparticles may, perhaps, explain the negative antibacterial activity obtained in our study; however, it does not elucidate why an inhibition halo could be seen for the gelatin-based matrix during the first experiment. However, in the third experiment, $\mathrm{CaO}$ nanoparticles were calcined as previously described [45] and then used for preparation of new $\mathrm{CaO}$ suspensions and tested against $S$. aureus. Once 
again, no antibacterial effect was observed. Taken together, the findings of the antibacterial test performed in the present study were inconclusive. Therefore, it can be suggested that something related to the nanoparticles used here had a limited aspect regarding their antibacterial potential; however, it is noteworthy that there are still a few studies in the literature showing that $\mathrm{CaO}$ nanoparticles can kill bacteria; therefore, further research focusing on the antibacterial activity of $\mathrm{CaO}$ nanoparticles against different bacteria should be performed.

Despite the lack of antibacterial properties displayed by the CaO-loaded matrices, osteoprecursor MC3T3-E1 cell viability was considered overall to be very satisfactory, as shown in Figs. 6 and 7. According to previous studies, electrospun PCL- and gelatin-based fibers were both considered excellent substrates for cell growth [39, 46-48], probably because the fibers obtained may resemble the extracellular matrix of native bone tissues. More importantly, the incorporation of compounds based on calcium (e.g., hydroxyapatite, calcium phosphate, and calcium carbonate) has been shown to be a promising approach to enhancing osteogenic ability, and thus bone regeneration [25-27, 49]. Consequently, it could be expected that osteoprecursor cells would present an affinity to the $\mathrm{CaO}$ loaded matrices processed here. Nevertheless, it is also important to note that the PCL matrix containing $15 \mathrm{wt} \%$ of $\mathrm{CaO}$ displayed low viability after 7 days of culture and, considering this negative result, it can be inferred that higher concentrations $(>10 \mathrm{wt} \%)$ of $\mathrm{CaO}$ would be harmful to the cells. Notwithstanding, the PCL/GEL matrix, which was also constituted of $15 \mathrm{wt} \%$ of $\mathrm{CaO}$, produced the highest level of cell growth, so it seems that this amount of nanoparticles is not detrimental to cells, but it serves as another characteristic of the PCL matrix that was different from the gelatin-based matrix. One possible explanation is the clear difference in architecture/ morphology of fibers; indeed, while the PCL/GEL matrix demonstrated thicker fibers with high porosity, the PCL matrix presented thinner fibers with significantly reduced porosity (Fig. 1). Taking into consideration that porosity is necessary for cell spreading and infiltration [35, 50], the MC3T3-E1 cells could not easily attach and proliferate over the low porous matrix, which was also confirmed by the absence of pseudopodia extensions in the SEM images of the PCL matrix containing $15 \mathrm{wt} \%$ of $\mathrm{CaO}$ (Fig. 7). Therefore, depending on the polymer system used, the addition of $\mathrm{CaO}$ can negatively affect the porosity level of the matrix, thus leading to important consequences to cell viability and proliferation. Meanwhile, another interesting finding of this study was that the gelatin-based matrix containing $\mathrm{CaO}$ nanoparticles produced excellent cell adhesion and viability, which was sometimes higher than the other matrices tested (Figs. 6 and 7). According to the results shown in Fig. 4, the PCL/GEL matrix was hydrophilic compared to the hydrophobic PCL-based matrices. Considering that hydrophilic matrices/scaffolds may increase cell viability, the positive cell response obtained here corroborates with previous studies
[36-40]. Interestingly, the present findings also agree with a previous study, which indicated that cell proliferation increased over time [51]. Previous studies reported on the enhanced mineralized matrix nodule formation in the presence of high $\mathrm{Ca}$ ion concentrations in dental pulp stem cells [52] and osteoblasts [53]. Here, an increased osteogenic differentiation of osteoprecursor cells in CaO-loaded matrices was noticed, which might be due to the release of calcium ions. Surprisingly, there was a decrease in ALP levels for the gelatin-containing CaOloaded matrix, the reason of which should be further explored.

\section{Conclusion}

Taken together, the present findings demonstrated that $\mathrm{CaO}$ nanoparticles can successfully be incorporated into electrospun PCL or PCL/GEL fibers without negatively affecting the overall performance of the matrices. Furthermore, a consistent antibacterial activity against $S$. aureus was not observed using these nanoparticles. On the other hand, our data confirmed that the PCL matrices containing $\mathrm{CaO}$ served as a good substrate for preosteoblasts viability, adhesion, and differentiation, thus still presenting a potential application for bone tissue engineering purposes.

Acknowledgments We acknowledge the expert assistance of Dr. Maria Malgorzata Kamocka with the confocal/2-photon imaging at the Indiana Center for Biological Microscopy, Indianapolis, IN.

\section{Compliance with ethical standards}

Funding This study was funded in part by an International Development Funds (IDF) Grant from Indiana University Purdue University (IUPUI/OVCR), by start-up funds from the IU School of Dentistry, and the NIH-NIDCR (Grant \# DE023552) (all to M.C.B.). In addition, this project was supported by the Indiana Clinical and Translational Sciences Institute, funded in part by grant \#UL1 TR001108 from the National Institutes of Health, National Center for Advancing Translational Sciences, Clinical and Translational Sciences Award. The content is solely the responsibility of the authors and does not necessarily represent the official views of the National Institutes of Health.

Conflict of interest The authors declare that they have no conflict of interest.

Ethical approval This article does not contain any studies with human participants or animals performed by any of the authors.

\section{References}

1. Boskey AL (2013) Bone composition: relationship to bone fragility and antiosteoporotic drug effects. Bonekey Rep 2:447. doi:10. 1038/bonekey.2013.181 
2. Patzakis MJ, Zalavras CG (2005) Chronic posttraumatic osteomyelitis and infected nonunion of the tibia: current management concepts. J Am Acad Orthop Surg 13:417-427

3. Tamazawa G, Ito A, Miyai T, Matsuno T, Kitahara K, Sogo Y, Kimishima K, Satoh T (2011) Gatifloxacine-loaded PLGA and beta-tricalcium phosphate composite for treating osteomyelitis. Dent Mater J 30:264-273

4. Romano CL, Logoluso N, Meani E, Romano D, De Vecchi E, Vassena C, Drago L (2014) A comparative study of the use of bioactive glass S53P4 and antibiotic-loaded calcium-based bone substitutes in the treatment of chronic osteomyelitis: a retrospective comparative study. Bone Joint J 96-B:845-850. doi:10.1302/0301620X.96B6.33014

5. Patwardhan S, Shyam AK, Mody RA, Sancheti PK, Mehta R, Agrawat H (2013) Reconstruction of bone defects after osteomyelitis with nonvascularized fibular graft: a retrospective study in twenty-six children. J Bone Joint Surg Am 95:e561-e566. doi:10. 2106/JBJS.K.01338

6. Liu RW, Abaza H, Mehta P, Bauer J, Cooperman DR, Gilmore A (2013) Intravenous versus oral outpatient antibiotic therapy for pediatric acute osteomyelitis. Iowa Orthop J 33:208-212

7. Kurikchy MQ, Al-Rawi NH, Ayoub RS, Mohammed SS (2013) Histological evaluation of bone healing using organic bovine bone in combination with platelet-rich plasma (an experimental study on rabbits). Clin Oral Investig 17:897-904. doi:10.1007/s00784-0120751-z

8. Miron RJ, Wei L, Bosshardt DD, Buser D, Sculean A, Zhang Y (2014) Effects of enamel matrix proteins in combination with a bovine-derived natural bone mineral for the repair of bone defects. Clin Oral Investig 18:471-478. doi:10.1007/s00784-013-0992-5

9. Mutlu I, Aydintug YS, Kaya A, Bayar GR, Suer BT, Gulses A (2012) The evaluation of the effects of hyperbaric oxygen therapy on new bone formation obtained by distraction osteogenesis in terms of consolidation periods. Clin Oral Investig 16:1363-1370. doi:10.1007/s00784-011-0644-6

10. Nguyen LT, Min YK, Lee BT (2015) Nanoparticle biphasic calcium phosphate loading on gelatin-pectin scaffold for improved bone regeneration. Tissue Eng Part A. doi:10.1089/ten.TEA.2014.0313

11. Mohammadi R, Amini K (2015) Guided bone regeneration of mandibles using chitosan scaffold seeded with characterized uncultured omental adipose-derived stromal vascular fraction: an animal study. Int J Oral Maxillofac Implants 30:216-222. doi:10.11607/jomi. 3542

12. Zhang Y, Miron RJ, Li S, Shi B, Sculean A, Cheng X (2015) Novel mesoporous BioGlass/silk scaffold containing adPDGF-B and adBMP7 for the repair of periodontal defects in beagle dogs. J Clin Periodontol. doi:10.1111/jcpe.12364

13. Bottino MC, Thomas V, Schmidt G, Vohra YK, Chu TM, Kowolik MJ, Janowski GM (2012) Recent advances in the development of GTR/GBR membranes for periodontal regeneration - a materials perspective. Dent Mater 28:703-721. doi:10.1016/j.dental.2012. 04.022

14. Lin L, Gao H, Dong Y (2015) Bone regeneration using a freezedried 3D gradient-structured scaffold incorporating OIC-A006loaded PLGA microspheres based on beta-TCP/PLGA. J Mater Sci Mater Med 26:5327. doi:10.1007/s10856-014-5327-9

15. Augustine R, Malik HN, Singhal DK, Mukherjee A, Malakar D, Kalarikkal N, Thomas S (2014) Electrospun polycaprolactone/ZnO nanocomposite membranes as biomaterials with antibacterial and cell adhesion properties. J Polym Res 21

16. Bottino MC, Kamocki K, Yassen GH, Platt JA, Vail MM, Ehrlich Y, Spolnik KJ, Gregory RL (2013) Bioactive nanofibrous scaffolds for regenerative endodontics. J Dent Res 92:963-969. doi:10.1177/ 0022034513505770

17. Bottino MC, Thomas V, Janowski GM (2011) A novel spatially designed and functionally graded electrospun membrane for periodontal regeneration. Acta Biomater 7:216-224. doi:10.1016/ j.actbio.2010.08.019

18. Cheng CF, Wu KM, Chen YT, Hung SL (2013) Bacterial adhesion to antibiotic-loaded guided tissue regeneration membranes-a scanning electron microscopy study. J Formos Med Assoc 114: 35-45. doi:10.1016/j.jfma.2013.07.010

19. Palasuk J, Kamocki K, Hippenmeyer L, Platt JA, Spolnik KJ, Gregory RL, Bottino MC (2014) Bimix antimicrobial scaffolds for regenerative endodontics. J Endod 40:1879-1884. doi:10. 1016/j.joen.2014.07.017

20. Waeiss RA, Negrini TC, Arthur RA, Bottino MC (2014) Antimicrobial effects of drug-containing electrospun matrices on osteomyelitis-associated pathogens. J Oral Maxillofac Surg 72: 1310-1319. doi:10.1016/j.joms.2014.01.007

21. Chuensombat S, Khemaleelakul S, Chattipakorn S, Srisuwan T (2013) Cytotoxic effects and antibacterial efficacy of a 3antibiotic combination: an in vitro study. J Endod 39:813-819. doi:10.1016/j.joen.2012.11.041

22. Ferreira MB, Myiagi S, Nogales CG, Campos MS, Lage-Marques JL (2010) Time- and concentration-dependent cytotoxicity of antibiotics used in endodontic therapy. J Appl Oral Sci 18:259-263

23. Bottino MC, Arthur RA, Waeiss RA, Kamocki K, Gregson KS, Gregory RL (2014) Biodegradable nanofibrous drug delivery systems: effects of metronidazole and ciprofloxacin on periodontopathogens and commensal oral bacteria. Clin Oral Investig 18:2151-2158. doi:10.1007/s00784-014-1201-x

24. Roy A, Gauri SS, Bhattacharya M, Bhattacharya J (2013) Antimicrobial activity of $\mathrm{CaO}$ nanoparticles. J Biomed Nanotechnol 9:1570-1578

25. Sawai J, Yoshikawa T (2004) Quantitative evaluation of antifungal activity of metallic oxide powders $(\mathrm{MgO}, \mathrm{CaO}$ and $\mathrm{ZnO})$ by an indirect conductimetric assay. J Appl Microbiol 96:803-809

26. Shi S, Zhou J, Han S, Ye J (2010) Luminescence and energy transfer of organic chromophores bound to inorganic nano-lamellar frameworks. J Nanosci Nanotechnol 10:1834-1838

27. Nandakumar A, Yang L, Habibovic P, van Blitterswijk C (2010) Calcium phosphate coated electrospun fiber matrices as scaffolds for bone tissue engineering. Langmuir 26:7380-7387. doi:10.1021/ la904406b

28. Seol YJ, Kim KH, Kang YM, Kim IA, Rhee SH (2009) Bioactivity, pre-osteoblastic cell responses, and osteoconductivity evaluations of the electrospun non-woven $\mathrm{SiO} 2-\mathrm{CaO}$ gel fabrics. J Biomed Mater Res B Appl Biomater 90:679-687. doi:10.1002/jbm.b.31334

29. Seol YJ, Kim KH, Kim IA, Rhee SH (2010) Osteoconductive and degradable electrospun nonwoven poly(epsilon-caprolactone)/ CaO-SiO2 gel composite fabric. J Biomed Mater Res A 94:649659. doi: $10.1002 / \mathrm{jbm} . \mathrm{a} .32738$

30. Münchow EA, Albuquerque MT, Zero B, Kamocki K, Piva E, Gregory RL, Bottino MC (2015) Development and characterization of novel $\mathrm{ZnO}$-loaded electrospun membranes for periodontal regeneration. Dent Mater 31:1038-1051. doi:10.1016/j.dental.2015.06. 004

31. Ilharreborde B (2014) Sequelae of pediatric osteoarticular infection. Orthop Traumatol Surg Res 101:S129-S137. doi:10.1016/j.otsr. 2014.07.029

32. Prasad SC, Prasad KC, Kumar A, Thada ND, Rao P, Chalasani S (2014) Osteomyelitis of the temporal bone: terminology, diagnosis, and management. J Neurol Surg B Skull Base 75:324-331. doi:10. 1055/s-0034-1372468

33. K-hasuwan PR, Pavasant P, Supaphol P (2011) Effect of the surface topography of electrospun poly(epsilon-caprolactone)/poly(3hydroxybuterate-co-3-hydroxyvalerate) fibrous substrates on cultured bone cell behavior. Langmuir 27:10938-10946. doi:10. 1021/la202255w

34. Dargaville BL, Vaquette C, Rasoul F, Cooper-White JJ, Campbell JH, Whittaker AK (2013) Electrospinning and crosslinking of low- 
molecular-weight poly(trimethylene carbonate-co-(L)-lactide) as an elastomeric scaffold for vascular engineering. Acta Biomater 9: 6885-6897. doi:10.1016/j.actbio.2013.02.009

35. Rnjak-Kovacina J, Wise SG, Li Z, Maitz PK, Young CJ, Wang Y, Weiss AS (2011) Tailoring the porosity and pore size of electrospun synthetic human elastin scaffolds for dermal tissue engineering. Biomaterials 32:6729-6736. doi:10.1016/j.biomaterials.2011.05.065

36. Busscher HJ, Stokroos I, Golverdingen JG, Schakenraad JM (1991) Adhesion and spreading of human fibroblasts on superhydrophobic Fep-teflon. Cell Mater 1:243-249

37. Lee J, Tae G, Kim YH, Park IS, Kim SH, Kim SH (2008) The effect of gelatin incorporation into electrospun poly(L-lactide-co-epsiloncaprolactone) fibers on mechanical properties and cytocompatibility. Biomaterials 29:1872-1879. doi:10.1016/j. biomaterials.2007.12.029

38. Phipps MC, Clem WC, Catledge SA, Xu Y, Hennessy KM, Thomas V, Jablonsky MJ, Chowdhury S, Stanishevsky AV, Vohra YK, Bellis SL (2011) Mesenchymal stem cell responses to bonemimetic electrospun matrices composed of polycaprolactone, collagen I and nanoparticulate hydroxyapatite. PLoS One 6:e16813. doi:10.1371/journal.pone.0016813

39. Zhang Y, Ouyang H, Lim CT, Ramakrishna S, Huang ZM (2005) Electrospinning of gelatin fibers and gelatin/PCL composite fibrous scaffolds. J Biomed Mater Res B Appl Biomater 72:156-165. doi: 10.1002/jbm.b.30128

40. Zheng R, Duan H, Xue J, Liu Y, Feng B, Zhao S, Zhu Y, Liu Y, He A, Zhang W, Liu W, Cao Y, Zhou G (2014) The influence of gelatin/PCL ratio and 3-D construct shape of electrospun membranes on cartilage regeneration. Biomaterials 35:152-164. doi: 10.1016/j.biomaterials.2013.09.082

41. Rajzer I, Menaszek E, Kwiatkowski R, Planell JA, Castano O (2014) Electrospun gelatin/poly(epsilon-caprolactone) fibrous scaffold modified with calcium phosphate for bone tissue engineering. Mater Sci Eng C Mater Biol Appl 44:183-190. doi:10.1016/j.msec. 2014.08.017

42. Li X, Xie J, Yuan X, Xia Y (2008) Coating electrospun poly(epsilon-caprolactone) fibers with gelatin and calcium phosphate and their use as biomimetic scaffolds for bone tissue engineering. Langmuir 24:14145-14150. doi:10.1021/la802984a

43. Nelson MT, Johnson J, Lannutti J (2014) Media-based effects on the hydrolytic degradation and crystallization of electrospun synthetic-biologic blends. J Mater Sci Mater Med 25:297-309. doi:10.1007/s10856-013-5077-0
44. Vargas-Reus MA, Memarzadeh K, Huang J, Ren GG, Allaker RP (2012) Antimicrobial activity of nanoparticulate metal oxides against peri-implantitis pathogens. Int $\mathbf{J}$ Antimicrob Agents 40: 135-139. doi:10.1016/j.ijantimicag.2012.04.012

45. Tang ZX, Yu Z, Zhang ZL, Zhang XY, Pan QQ, Shi LE (2013) Sonication-assisted preparation of $\mathrm{CaO}$ nanoparticles for antibacterial agents. Química Nov. 36:933-936

46. Jeong SI, Lee AY, Lee YM, Shin H (2008) Electrospun gelatin/ poly(L-lactide-co-epsilon-caprolactone) nanofibers for mechanically functional tissue-engineering scaffolds. J Biomater Sci Polym Ed 19:339-357. doi:10.1163/156856208783721029

47. Kai D, Prabhakaran MP, Stahl B, Eblenkamp M, Wintermantel E, Ramakrishna S (2012) Mechanical properties and in vitro behavior of nanofiber-hydrogel composites for tissue engineering applications. Nanotechnology 23:095705. doi:10.1088/0957-4484/23/9/ 095705

48. Xue J, Feng B, Zheng R, Lu Y, Zhou G, Liu W, Cao Y, Zhang Y, Zhang WJ (2013) Engineering ear-shaped cartilage using electrospun fibrous membranes of gelatin/polycaprolactone. Biomaterials 34:2624-2631. doi:10.1016/j.biomaterials.2012.12. 011

49. Lao L, Wang Y, Zhu Y, Zhang Y, Gao C (2011) Poly(lactide-coglycolide)/hydroxyapatite nanofibrous scaffolds fabricated by electrospinning for bone tissue engineering. J Mater Sci Mater Med 22:1873-1884. doi:10.1007/s10856-011-4374-8

50. Soliman S, Sant S, Nichol JW, Khabiry M, Traversa E, Khademhosseini A (2011) Controlling the porosity of fibrous scaffolds by modulating the fiber diameter and packing density. J Biomed Mater Res A 96:566-574. doi:10.1002/jbm.a.33010

51. Ni P, Fu S, Fan M, Guo G, Shi S, Peng J, Luo F, Qian Z (2011) Preparation of poly(ethylene glycol)/polylactide hybrid fibrous scaffolds for bone tissue engineering. Int J Nanomedicine 6:30653075. doi:10.2147/IJN.S25297

52. An S, Gao Y, Ling J, Wei X, Xiao Y (2012) Calcium ions promote osteogenic differentiation and mineralization of human dental pulp cells: implications for pulp capping materials. J Mater Sci Mater Med 23:789-795. doi:10.1007/s10856-011-4531-0

53. Nakamura S, Matsumoto T, Sasaki J, Egusa H, Lee KY, Nakano T, Sohmura T, Nakahira A (2010) Effect of calcium ion concentrations on osteogenic differentiation and hematopoietic stem cell nicherelated protein expression in osteoblasts. Tissue Eng Part A 16: 2467-2473. doi:10.1089/ten.TEA.2009.0337 